УДК: 351

https://doi.org/10.32689/2618-0065-2020-3(5)-239-249

Хассун Мухамед Абдель Маджет, аспірант кафедри публічного адміністрування, Міжрегіональна Академія управління персоналом, вулиця Фрометівська, 2, Київ, 02000, тел.: $044 \quad 490$ 9505, email: hassunmuhamed@ukr.net, https//orcid.org/0000-0003-2103-5651

\title{
АНАЛІЗ ПОНЯТІЙНО-КАТЕГОРІАЛЬНОГО АПАРАТУ ДЕРЖАВНОЇ ПОЛІТИКИ У СФЕРІ ДИПЛОМАТИЧНИХ ВІДНОСИН
}

Анотація: визначено, що, на сучасному етапі розвитку державного управління у сфері дипломатичних відносин, важливим аспектом дослідження $\epsilon$ аналіз науково-теоретичних основ механізмів державного управління цього напряму: дефініцій термінів «державна політика», «механізм державного управління», «дипломатія», «дипломатичні відносини» та інших з цим пов'язаних визначень, що дозволить збільшити результативність діяльності системи державного управління, у цілому. Обгрунтовано, що державна політика комплексно характеризує діяльність держави у відповідній сфері, визначає стратегічні цілі та завдання влади, а розв'язання конкретних громадських проблемних питань $є$ однією з ії̈ частин.

Відмічено, що головним засобом впровадження державно-виконавчої влади $\epsilon$ саме механізм управління нею. Одночасно, будучи єдиним комплексом окремих елементів соціуму у їх органічному взаємозв'язку, а, також, поєднанням певних процесів та закономірностей, суб'єкт цього механізму визначає інтереси та потреби суспільного розвитку, утверджує рішення та дії, на цій основі, i, нарешті, впроваджує у життя рішення відповідних проблем, зважаючи на державно-владний контекст.

Обгрунтовано, що у ракурсі системної концепції, механізм державного управління включає взаємозв'язки між ії суб'єктом і об'єктом управління, забезпечує здійснення функцій держави у рамках законодавчо закріпленої сфери державно-управлінського впливу та сприяе цілісності системи державного адміністрування. Зроблено висновок про те, що в енциклопедичних визначеннях дипломатія використовується як синонім зовнішньої політики держави. Отже, поняття дипломатичної діяльності ототожнюється з поняттям зовнішньої політики. Однак, така точка зору не досить детально розкриває зміст терміну та $\epsilon$ не цілком коректною. Адже визначення дипломатії $\epsilon$ набагато вужчим, аніж визначення зовнішньої політики і $\epsilon$, скоріше, однією зі складових зовнішньої політики, засобом іiї здійснення, що встановлює взаємозв'язки між суб'єктами зовнішньополітичних зносин. 
Ключові слова: механізми державного управління, дипломатичні відносини, зовнішньополітичні зносини, потреби суспільного розвитку, захист інтересів держави.

Hassun Muhamed Abdel Majid, Postgraduate Student, Department of Public Administration, Interregional Academy of Personnel Management, 2 Frometivska Street, Kyiv, 02000, tel.: 044490 9505, email: hassunmuhamed@ukr.net, https//orcid.org/0000-0003-2103-5651

\title{
Analysis of the conceptual-categorical apparatus of state policy in the field of diplomatic relations
}

\begin{abstract}
: it is determined that, at the present stage of the development of public administration in the field of diplomatic relations, an important aspect of the research is the analysis of the scientific and theoretical foundations of the mechanisms of public administration in this area: definitions of the terms «public policy», «mechanism of public administration», «diplomacy», «diplomatic relations» and other related definitions, which will increase the effectiveness of the public administration system as a whole. It is substantiated that state policy comprehensively characterizes the activities of the state in the relevant sphere, defines the strategic goals and tasks of the authorities, and the resolution of specific public problems is one of its parts.

It is noted that the main means of implementation of the state-executive power is the mechanism of its management. At the same time, being the only complex of individual elements of society in their organic interconnection, as well as by combining certain processes and patterns, the subject of this mechanism determines the interests and needs of social development, approves decisions and actions, on this basis, and, finally, implements solutions to relevant problems, taking into account the state-governmental context.

It is substantiated that in the context of the system concept, the mechanism of public administration includes the interconnections between its subject and the object of management, ensures the implementation of the functions of the state within the framework of legislatively fixed sphere of governmental influence and promotes the integrity of the system of public administration. It is concluded that in encyclopedic definitions, diplomacy is used as a synonym for foreign policy. Thus, the concept of diplomatic activity is identical with that of foreign policy. However, such a view does not sufficiently disclose the meaning of the term and is not entirely correct. Indeed, the definition of diplomacy is much narrower than the definition of foreign policy and is, rather, one of the components of foreign policy, a means of its implementation, which establishes relations between the subjects of foreign policy relations.
\end{abstract}

Keywords: mechanisms of public administration, diplomatic relations, foreign policy relations, needs of social development, protection of interests of the state. 
Постановка проблеми. На сучасному етапі розвитку державного управління у сфері дипломатичних відносин, важливим аспектом дослідження $\epsilon$ аналіз науково-теоретичних основ механізмів державного управління цього напряму: дефініцій термінів «державна політика», «механізм державного управління», «дипломатія», «дипломатичні відносини» та інших з цим пов'язаних визначень, що дозволить збільшити результативність діяльності системи державного управління, у цілому. Ефективність даної системи залежить від вдалого функціонування структур, що забезпечують цілеспрямоване та скоординоване управління міжнародними дипломатичними процесами держави, дієвий вплив управлінських механізмів на міжнародний дипломатичний розвиток країни, впровадження у життя цілей та завдань державного управління у сфері дипломатичних відносин, які слід реалізовувати у відповідних напрямах суспільного існування.

В контексті даного дослідження, необхідно відзначити практичну важливість, актуальність дослідження та визначення понятійнокатегоріального апарату державної політики у сфері дипломатичних відносин. Насамперед, це передбачає аналіз поглядів вітчизняних дослідників галузі державного управління у висвітленні теоретичних засад, ключових термінів та категорій державної політики у сфері дипломатичних відносин та типологізацію підходів до їх класифікації [1].

Аналіз останніх досліджень та публікацій. Впродовж останнього часу, вивчення механізмів державного управління у сфері дипломатичних відносин.перебуває у сфері наукових пріоритетів багатьох вітчизняних науковців, серед яких: Г. Атаманчук, В. Бакуменко, Б. Гаєвський, Н. Дацій, О. Драган, М. Круглов, І. Кринична, В. Малиновський, О. Оболенський, Р. Рудницька, Ю. Тихомиров, О. Федорчак та ін. Однак, на сьогоднішній день, має місце «криза» змістовної інтерпретації та одностайності у термінологічному значенні цього поняття, незважаючи на значну кількість досліджень сфери публічного адміністрування у напрямі теоретикометодологічного розвитку суті механізмів державного управління.

Мета статті. Метою статті є аналіз понятійно-категоріального апарату державної політики у сфері дипломатичних відносин.

Виклад основного матеріалу. Основним елементом терміну «державна політика у сфері дипломатичних відносин» $є$ поняття державної політики. Висвітлення цього терміну вітчизняними науковцями подано у табл.1.

Таблиця 1.

Аналіз визначення поняття «державна політика» вітчизняними авторами

\begin{tabular}{|l|c|}
\hline \multicolumn{1}{|c|}{ Автор } & Визначення поняття \\
\hline O. Кілісвич, & Організований органами державної влади напрям дій (або \\
\hline
\end{tabular}




\begin{tabular}{|c|c|}
\hline В. Тертичка [2] & $\begin{array}{l}\text { бездіяльності), зорієнтований на вирішення комплексу } \\
\text { взаємопов'язаних проблем або певної проблеми соціуму }\end{array}$ \\
\hline I. Розпутенко [3] & $\begin{array}{l}\text { Сукупність дій повноважних органів влади, спрямованих на } \\
\text { досягнення відповідних цілей та роботу у відповідних } \\
\text { напрямах діяльності, спрямованих на вирішення певних } \\
\text { суспільних проблем }\end{array}$ \\
\hline B. Kynрiй [4] & $\begin{array}{l}\text { Комплекс безперервних, циклічних, послідовних дій, } \\
\text { функціональних взаємодій складових, інституційних } \\
\text { структур та засобів, які направлені на досягнення } \\
\text { відповідного результату }\end{array}$ \\
\hline Е. Афонін [5] & $\begin{array}{l}\text { Діяльність органів державної влади та їх посадових осіб щодо } \\
\text { реалізації визначеної політики, спрямованої на регулювання } \\
\text { політичних, соціальних та економічних процесів у суспільстві }\end{array}$ \\
\hline Р. Кобеиь [6] & 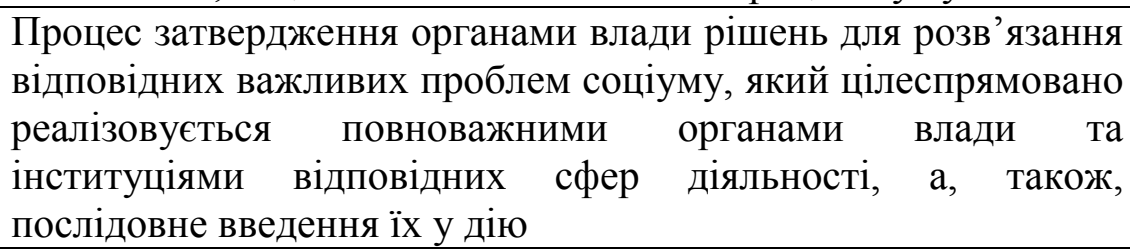 \\
\hline A. Мерзляк [7] & $\begin{array}{l}\text { Система комплексних дій, стратегічно направлених цілей та } \\
\text { положень повноважних державно-владних органів, яка } \\
\text { орієнтована на розв'язання потреб, чи проблем, які виникли } \\
\text { на даному етапі розвитку держави, які визначають курс } \\
\text { впровадження у життя цих цілей, у ході організаційно- } \\
\text { управлінської діяльності у сфері суспільного розвитку } 3 \\
\text { обов'язковим урахуванням інтересів громадян }\end{array}$ \\
\hline
\end{tabular}

Як бачимо (табл.1), у державно-управлінській науці поняття «державної політики» розглядається не достатньо широко та розгалужено, щоб повністю розкрити його зміст та не $є$ цілком коректним. Проаналізуємо кожне 3 визначень окремо.

О. Кілієвич, В. Тертичка розкривають поняття «державна політика» не тільки як дії, але і як утримання від них (бездіяльність). В контексті цього визначення, влада окреслюється як носій політики, а політика - як заходи, вжиті державними структурами, які мають можливість вибору як саме діяти та чи робити взагалі що-небудь.

3 позиції І. Розпутенка «державна політика» визначається як реакція на громадські проблемні питання. Така точка зору не виявляє повного змісту цього терміну, адже державна політика, основним завданням якої $\epsilon$ розв'язання конкретного громадського проблемного питання, визначає коротко терміновість своєї діяльності, а звідси випливає, що вона втратить своє функціональне значення тоді, коли це питання буде вирішене. До того ж впровадження та реалізація державної політики залежить не тільки від присутності певного проблемного питання у відповідній сфері життєдіяльності країни.

Одночасно, 3 визначеними характеристиками цього поняття можна сказати що «державна політика» здійснюється безперервно. Отже, можна 
зробити висновок, що державна політика комплексно характеризує діяльність держави у відповідній сфері, визначає стратегічні цілі та завдання влади, а розв’язання конкретних громадських проблемних питань є однією з їі частин. 3 цієї точки зору, мають вагому роль у державно-управлінській науці визначення «державної політики», подані В. Купрієм та Е. Афоніним. Можна погодитись 3 цим визначенням у контексті функціонування державної політики, як безперервного процесу, заснованого на монопольному праві країни розв’ язувати відповідні проблеми.

Термін «державна політика» предметно розглядає у своїх роботах Р. Кобець. На нашу думку, дане поняття є дещо двозначним. 3 одного боку, державна політика розглядається як процес ухвалення рішення, яке реалізується державними структурами, а з іншого - як хід підготовки та реалізації політики у відповідній сфері, що є складним процесом взаємодії суб’єктів структури, у кожного з яких є свої цілі та завдання.

Найбільш комплексним та показовим, на нашу думку, є визначення А. Мерзляка, в якому державна політика визначається як засіб гармонізації та інтегрованості суспільства, наслідком ефективного функціонування якого буде покращення якості життя людей та забезпечення стабільності у всіх сферах їхньої діяльності.

У контексті наукових поглядів М. Круглова [8, с. 111], механізм державного управління визначається як комплекс організаційних, економічних, політичних і мотиваційних способів безпосереднього впливу учасників процесу державного управління на діяльність об'єктів, які забезпечують координацію інтересів суб'єктів державного управління, які взаємодіють між собою. У рамках цього визначення, можна зробити висновок, що комплексний механізм державного управління повинен бути системним і охоплювати та координувати усі сфери діяльності управління державою: політику, економіку, право та інші.

Цікавим $є$ визначення механізму державного управління дане Г. Атаманчуком [9, с. 86], який розглядає його як організовану, згідно певних принципів, складну структурну систему, яка направлена на вирішення цілей та завдань публічного адміністрування. Я, частково, погоджуюся із даною думкою, адже головним засобом впровадження державно-виконавчої влади $є$ саме механізм управління нею. Одночасно, будучи єдиним комплексом окремих елементів соціуму у їх органічному взаємозв'язку, а, також, поєднанням певних процесів та закономірностей, суб’єкт цього механізму визначає інтереси та потреби суспільного розвитку, утверджує рішення та дії, на цій основі, i, нарешті, впроваджує у життя рішення відповідних проблем, зважаючи на державно-владний контекст.

Беручи до уваги позицію Ю. Тихомирова [10, с. 482-483], який під механізмом державного управління розуміє сукупність прийомів координації та функцій адміністрування, що засновані на виявленні цілей, науковому та практичному їх обгрунтуваннях, процесі еволюції системи керування, яка гарантує здійснення завдань та досягнення стратегічних цілей у процесі управління, можна погодись з цією думкою, адже вона дозволяє визначати 
механізми державного управління як результативний інструмент для пізнання дійсності та обгрунтованого впливу на суспільні процеси реалізації державних функцій.

Достатньо глибоко вивчали структуру і зміст механізмів державного управління I. Драган, І. Дацій, І. Кринична [11, с. 53-54], О. Оболенський. Науковці сходяться у думці, що механізм державного управління представляє собою системну єдність органів місцевого самоврядування та центральних органів державної влади, діяльність яких заснована на відповідних законодавчо закріплених положеннях, реалізація яких базується на функціональному розподілі влади та наявності важливих ресурсів. Погоджуючись 3 авторами, можна зважено говорити, що у ракурсі системної концепції, механізм державного управління включає взаємозв'язки між іiі суб'єктом і об’єктом управління, забезпечує здійснення функцій держави у рамках законодавчо закріпленої сфери державно-управлінського впливу та сприяє цілісності системи державного адміністрування.

Н. Нижник та О. Машков [12, с. 37] розробили своє бачення поняття «механізм державного управління», згідно 3 яким він окреслюється як самостійний компонент системи адміністрування, який забезпечує безпосередній вплив на велике різномаїття факторів, від стану яких залежать результати та наслідки функціонування об'єкта управління. Узагальнючи позицію авторів, можна зробити висновок, що процеси управлінської діяльності у загальній системі управління виникають та функціонують в межах окремих організаційних структур, що має вагомий вплив на усі сфери розвитку держави

Механізм державного управління, у розумінні В. Авер'янова [13, с. 35] - це система відповідних повноважних органів державної влади, яка забезпечує досягнення цілей державного управління відповідно від їх правового статусу та норм, які регламентують процеси організації та реалізації вказаними структурами свого функціонального призначення. На мою думку, згідно даного визначення через механізм державного управління виконується реалізація владних повноважень, що гарантує владі іiі автономність та легітимність. Отже, у певному порядку виникають владні відносини: відповідний інтерес окремої соціальної групи трансформується у суспільно-важливу політичну мету i тільки після цього, через механізм впровадження, мета перетворюється у суспільні владні відносини. Тому, можна зробити висновки, що незалежними складовими системи будь яких владних відносин є функціонування та реалізація цієї системи та певний механізм створення таких відносин.

Одним 3 найуніверсальніших, на мою думку, визначень поняття «механізм державного управління»є трактування, яке було запропоновано у науковому доробку О.Федорчака [14]. На основі фундаментального дослідження терміну, визначено, що механізм державного управління системний інструмент державно-владних органів, визначений для практичної реалізації державного управління та досягнення цілей, що ставить перед собою держава, який має відповідну структуру та методи впливу на об’єкт 
адміністрування відповідно до нормативно-правового, інформаційного та інших видів забезпечення. Однозначно, можна сказати, що у даному понятті, у повному обсязі, визначено структуру механізму державного управління, головними складовими якої, безпосередньо, є методи, важелі, інструменти, політика, правове та інші види забезпечення.

У контексті дослідження державної політики у сфері дипломатичних відносин, вважаю за потрібне проаналізувати наявні, на сьогоднішній день, вітчизняні наукові розробки концептуально-теоретичного напряму, який стосується визначення поняття «дипломатія», що закономірно пояснює актуальність питання розробки методологічного базису у вивченні сфери дипломатичних відносин як специфічного виду міжнародної діяльності.

Великий тлумачний словник української мови [15, с. 297] приводить таке визначення дипломатії як «діяльність керівництва держави та специфічних структур зовнішніх відносин в напрямі реалізації міжнародної зовнішньої політики та захисту інтересів держави за кордоном».

Найбільш розгалужену дефінцію даного терміну в словниках трактує Українська дипломатична енциклопедія [16], у якій вказано, що дипломатія «це спосіб реалізації зовнішньополітичної діяльності, внутрішнього регулювання державної влади, офіційна діяльність керівників держав та урядів, представницьких посадових осіб акредитуючих країн за кордоном та в державі».

Можна зробити висновок, що в енциклопедичних визначеннях дипломатія використовується як синонім зовнішньої політики держави. Отже, поняття дипломатичної діяльності ототожнюється 3 поняттям зовнішньої політики. Але, на мою думку, така точка зору не досить детально розкриває зміст терміну та $\epsilon$ не цілком коректною. Адже визначення дипломатії $\epsilon$ набагато вужчим, аніж визначення зовнішньої політики і $\epsilon$, скоріше, однією зі складових зовнішньої політики, засобом їі здійснення, що встановлює взаємозв'язки між суб'єктами зовнішньополітичних зносин.

В процесі дослідження, важливим аспектом у визначенні поняття дипломатії є дослідження вітчизняних вчених, які ми розглянемо нижче.

Найпростішим визначенням, на мою думку, є термін, запропонований Є. Онацьким [17], який окреслює поняття дипломатії як мистецтво досягати жаданого у міжнародних відносинах за допомогою переговорів. Тут має місце процес звуження значення дипломатії до одного із методів державного управління, який, також, має важливе значення, але не забезпечує виконання низки інших функцій i тому не є багатогранним та всеохоплюючим для реалізації державної політики у сфері дипломатичних відносин.

За словами О. Сагайдака [18, с. 62], дипломатія є наукою про публічне адміністрування у сфері міжнародних відносин та, одночасно, мистецтвом ведення переговорів керівниками держав та урядів, органами зовнішніх відносин, а, також, пояснює участь суб’єктів дипломатичних відносин у визначенні зовнішньополітичного курсу держави та його впровадження, реалізацію мирними засобами задля захисту інтересів держави та громадян. 
Погоджуюся 3 таким визначенням, адже така позиція майже 3 усіх сторін окреслює поняття дипломатії та встановлює причинно-наслідкові зв’язки діяльності державних органів та структур у сфері дипломатичних відносин з захистом інтересів держави та окремих громадян для реалізації сукупності зовнішньополітичних функцій держави у сфері міжнародних відносин.

Розглянемо дефініцію поняття «дипломатія», сформульовану П. Шляхтуном [19, с.427]: комунікації між державами, іiі органами влади у сфері зовнішніх відносин та комплекс інструментів їх безпосередньої реалізації шляхом здійснення офіційної діяльності керівників держав, урядів, органів міжнародних відносин та дипломатів, які підтримують процес досягнення цілей та завдань зовнішньополітичної діяльності задля забезпечення захисту інтересів держави та іiі громадян за кордоном. 3 цієї позиції, науковець розкриває сутність дипломатії не зовсім коректно, адже показовим $\epsilon$ iï визначення, в першу чергу, як комунікації, а вже потім як офіційної діяльності органів зовнішніх відносин.

Глибоко розкриває зміст поняття дипломатії В. Матвієнко [16, с. 629] в Українській дипломатичній енциклопедії: це офіційна діяльність глав держав та урядів, відомств закордонних справ, дипломатичних представництв та інших органів зовнішніх зносин 3 реалізації цілей i завдань зовнішньої політики держави, а, також, захисту прав та інтересів держави, іiі установ i громадян за кордоном лише мирним шляхом, засобами переговорів i домовленостей. Отже, у такому контексті визначення поняття дипломатії дає змогу встановити іï вирішальну критеріальну характеристику у галузі публічного адміністрування, а саме - застосування переговорів та домовленостей як основного засобу досягнення мирними засобами повноцінних стосунків між суверенними державами.

А. Панов [20, с. 6] окреслює дипломатію як інструмент довгострокової дії зовнішньої політики держави, який підтримує офіційні міждержавні відносини, здійснює представництво країни в акредитуючій державі, або у взаємодії з міжнародними організаціями, відстоює правові інтереси держави, громадян держави та юридичних осіб. Беручи за основу вищезазначене тлумачення, можемо визначити, що основною ознакою дипломатії $\epsilon$ довгостроковість діяльності, що має важливе значення у державноуправлінській науці у сфері дипломатичних відносин.

Висновки та перспективи подалыших досліджень. Отже, розглянувши думки щодо визначення поняття дипломатії у роботах вітчизняних науковців можна зробити висновки про іiі основні характерні ознаки, серед яких:

$\epsilon$ організаційно-політичним інструментом для реалізації зовнішньополітичного курсу держави;

представляє собою офіційну діяльність керівників держав та державних повноважних структур;

довгостроковість діяльності;

дипломатію часто розглядають у комплексі понятійно-категоріального апарату зовнішньої політики держави та міжнародних відносин; 
суб'єктами дипломатії виступають глави уряду та легітимні інституції (урядові установи та структури у сфері дипломатичних відносин та окремі індивіди-дипломати);

містить сукупність засобів і методів досягнення цілей та завдань зовнішньої політки держави, а, також, відстоювання та правового захисту законних інтересів держави та громадян за кордоном;

головними засобами здійснення дипломатії є переговори і домовленості.

\section{Лimepamypa:}

1. Кравченко О. М. Теоретичні підходи до визначення поняття “механізм державного управління. Державне управління: удосконалення та розвиток : електронне наукове фахове видання.2009. № 3. URL: http://www.dy.nayka. com.ua/index.php? operation=1\&iid=56 (дата звернення:20.05.2020).

2. Кілієвич О. І., Тертичка В. В. Державна політика: аналіз та механізми іiі впровадження : метод, рек. . К.: НАДУ, 2009. 88 с.

3. Енциклопедичний словник з державного управління / Ю.П. Сурмін, та ін. К.: НАДУ, 2010. $820 \mathrm{c}$.

4. Купрій, В.О. Організації громадянського суспільства як суб'єкти вироблення державної політики: автореф. дис... канд. наук з держ. упр.: 25.00.01 Національна академія держ. управління при Президентові України. К., 2007. 20 с.

5. Концептуальні засади взаємодії політики й управління : навч. посіб. / Е. А. Афонін та ін. К.: НАДУ, 2010. 300 с.

6. Кобець Р. Аналіз політики для потреб лобістської кампанії : навч. посіб. К.: Фонд Європа XXI: Т-во Лева, 2007. 212 с.

7. Мерзляк А. В., Кравченко Т. В. Державна політика у сфері управління соціальними ризиками: сутність, формування та реалізація .Наук.-виробн. журнал «Держава та регіони». Серія «Державне управління»2011.№ 1._URL: https://cutt.ly/oaRCWu2 (дата звернення:20.05.2020).

8. Круглов М. И. Стратегическое управление компанией. Москва: Русская деловая література, 1998.C.111.

9. Атаманчук Г. В. Теория государственного управлення. Курс лекций. М.: ОмегаЛ, $2005.584 \mathrm{c}$.

10. Тихомиров Ю. А. Курс административного права й процессаМ.: 1998.С. 482-483

11. Оболенський О.Ю. Державна служба: підручник. К.: КНЕУ, 2006.С. 53-54.

12. Нижник Н. Р. Системний підхід в організації державного управління: навч. посіб. К.: 1998.160 с .

13. Державне управління в Україні: навч. посіб. / В. Б. Авер'янов. К., 1998. 350 с.

14. Федорчак О. В. Класифікація механізмів державного управління Демократичне врядування: зб. наук. пр. Львів: ЛРІДУ НАДУ, 2008.Вип. 1.URL: http://www.nbuv.gov.ua/ejournals/DeVr/2008-01/O_Fedorchak.pdf (дата звернення: 20.05.2020)

15. Великий тлумачний словник сучасної української мови (з дод., допов. та $\mathrm{CD}$ ) / уклад. і голов. ред. В. Т. Бусел. Ірпінь : ВТФ "Перун", 2007. 1734 с.

16. Українська дипломатична енциклопедія : у 2-х т./ редкол.: Л. В. Губерський (голова) та ін. К. : Знання України, 2004. Т. 1.760 с.

17. Дипломатія. Украӥнська мала енииклопедія: 16 кн.: $у 8 \mathrm{m./}$ проф. Є. Онацький. Буенос-Айрес, 1958. Т. 2 : Д- С, кн. 3. С. 344.

18. Сагайдак О. П. Дипломатичний протокол і етикет :2-ге вид.К., 2006. 380 с.

19. Шляхтун П. П. Політологія: історія та теорія: Підручник К.: Центр учбової літератури, $2010.472 \mathrm{c}$.

20. Панов А.В. Дипломатична і консульська служба: монографія.Ужгород, ПП «АУТДОР-ШАРК». 2015. 270 c. 


\section{References:}

1. Kravchenko, O.M. (2009). Teoretichni pidhodi do viznachennja ponjattja "mehanizm derzhavnogo upravlinnja" [Theoretical approaches to the definition of the concept of "mechanism of public administration]. Derzhavne upravlinnja: udoskonalennja ta rozvitok Public administration: improvement and development, 3. Retrieved from http://www.dy.nayka. com.ua/index.php? operation=1\&iid=56 [in Ukrainian]

2. Kilievich, O.I. \& Tertichko, V.V. (2009). Derzhavna politika: analiz ta mehanizmi ï vprovadzhennja [State policy: analysis and mechanisms for its implementation]. K: NADU [in Ukrainian].

3. Surmin, V.D. Bakumenko, Mikhnenko, A.M. (2010). Enciklopedichnij slovnik z derzhavnogo upravlinnja [Encyclopedic Dictionary of Public Administration]. K: NADU [in Ukrainian].

4. Kupriy, V.O. (2007). Organizaciï gromadjans'kogo suspil'stva jak sub'єkti viroblennja derzhavnoï politiki [Civil society organizations as subjects of public policy making]. Extended abstract of candidate's thesis. Kiev: Kiev [in Ukrainian].

5. Afonin, E.A. Berezhnyi, Ya V. \& Valevsky, O.L. (2010). Konceptual'ni zasadi vza€modiï politiki j upravlinnja [Conceptual foundations of policy-management interaction] . K: NADU [in Ukrainian].

6. Kobets, R. (2007). Analiz politiki dlja potreb lobists'koï kampaniï [Policy Analysis for the Lobbying Campaign]. Kyiv: T-vo Leva [in Ukrainian].

7. Merzlyak, A.V. (2011) State Policy in the Field of Social Risk Management: Essence, Formation and Implementation [Derzhavna politika u sferi upravlinnja social'nimi rizikami: sutnist', formuvannja ta realizacija]. Derzhava ta regioni - States and Regions, 1. Retrieved from: http://www.nbuv.gov.ua/portal/Soc Gum/Dtr du/2010 4/files/DU410 40.pdf

8. Kruglov, M. I. (1998). Strategicheskoe upravlenie kompaniej [Strategic management of the company]. Moscow: Russkaja delovaja literatura [in Russian].

9. Atamanchuk, G.V. (2005). Teorija gosudarstvennogo upravlennja [The theory of government]. Moscow: Omega-L [in Russian].

10. Tikhomirov, Yu. A.. (1998). Kurs administrativnogo prava j processa [Course of administrative law and process]. Moscow: [in Russian].

11. Obolensky, O.Yu. (2006). Derzhavna sluzhba [Public service]. Kyiv: KNEU [in Ukrainian].

12. Nizhnik, N.R. (1998). Sistemnij pidhid v organizacii derzhavnogo upravlinnja [Systematic approach in the organization of public administration]. Kyiv: Znannia [in Ukrainian].

13. Averyanov, V.B. (1998). Derzhavne upravlinnja v Ukraïni [Public Administration in Ukraine]. Kyiv: Znannia [in Ukrainian].

14. Fedorchak, O.V. (2008). Klasifikacija mehanizmiv derzhavnogo upravlinnja [Classification of mechanisms of public administration]. Demokratichne vrjaduvannja Democratic governance, 1 . Retrieved from http://www.nbuv.gov.ua/e-journals/DeVr/2008-01/O Fedorchak.pdf

15. Busel, V.T. (2007). Velikij tlumachnij slovnik suchasnoï ukraïns'koï movi [The Great Interpretive Dictionary of Modern Ukrainian]. Kyiv: Perun [in Ukrainian].

16. Gubersky, L. (2004). Ukraïns'ka diplomatichna enciklopedija [Ukrainian Diplomatic Encyclopedia]. Kyiv: Znannia [in Ukrainian].

17. Onatsky, E. (1958). Ukraïns'ka mala enciklopedija [Ukrainian Small Encyclopedia]. (Vols. 1-7). Donetsk: YuhoVostok [in Ukrainian].

18. Sagaidak, O.P. (2006) Diplomatichnij protokol $i$ etiket [Diplomatic protocol and etiquette]. Kyiv: Znannia [in Ukrainian].

19. Shljahtun, P. P. (2010) Politologija: istorija ta teorija [Political Science: History and Theory]. Kyiv: Centr uchbovoï literaturi [in Ukrainian]. 
20. Panov, A.V. Diplomatichna i konsul's'ka sluzhba [Diplomatic and consular services]. Uzhgorod; PP «AUTDOR-ShARK» [in Ukrainian]. 